\title{
Economic and Innovative Factors Influence on Funding of the Supply-Side of Housing in Nairobi, Kenya
}

\author{
Faith W. Kanjumba \\ Correspondence: Faith Wambui Kanjumba, Chandaria School of Business, P.O Box 14634-0800 Nairobi, Kenya. E-mail: \\ fkanjumba@kanjumba.com
}

Received: April 5, 2017

doi:10.11114/bms.v3i4.2316
Accepted: August 23, 2017

Online Published: November 12, 2017

URL: https://doi.org/10.11114/bms.v3i4.2316

\begin{abstract}
Housing impact on an economy is undisputed. Economic factors comprising market forces, cost of inputs, the macro economy and the cost of funding are one set of factors that impacts on the funding of the supply-side of housing. Financiers' reactionary actions to encourage uptake of credit is undertaken by use of innovation and technology. This paper sets to establish the relationships between both economic and innovative factors, and funding of the supply-side of housing in Kenya and also the moderating effect of the major stakeholders. Using an explanatory form of approach in research design a survey was conducted using questionnaires to collect data from a random sample of 212 branches in Nairobi of financial institutions drawn from a population of 43 commercial banks, 9 deposit-taking MFIs and three major financiers of housing. Factor analysis, correlation analysis and ordinal logit regression were used to determine the relationships. A negative relationship between economic factors and funding of housing was found, while innovative financing and technological factors were found to have no influence. A positive moderating effect of stakeholders on the relationships between both economic factors, and innovative financing and technological factors on one side, and funding of housing was established. The implication being that economic factors play a bigger role in impacting housing and a stable economy is conducive in encouraging investments in housing, with government acting more as an enabler. Innovative financing and technology act as facilitators only.
\end{abstract}

Keywords: housing, funding, financial institutions, economic factors, innovative financing, technology

\section{Introduction}

Housing plays a major role to the economic development of a country. Mondejar, Cheung and Suen (2007) point out that the construction industry is one of the pillars of the world's economy and it is characterized by its temporary multiple organization nature, in that people with different skills and expertise come together to form a team for the duration of a project in order to achieve a common goal. According to the Economic Survey (2015), the construction industry in Kenya registered an accelerated growth of 13.1 per cent in 2014 compared to a revised growth of 5.8 per cent in 2013, reflected by the increase in both cement consumption by $21.8 \%$ and a $15.4 \%$ increase in the value of building plans approved by Nairobi City Council.

The demand for housing increases in response to several factors, notably urbanization and population growth (Doling, Vandenberg, and Tolentino, 2013). It is estimated by (UN-HABITAT, 2014) that by 2050, 70 percent of the world's population will be living in urban areas. Half of the world's adult population does not have an account at a formal financial institution, and $75 \%$ of poor people are "unbanked." This indicates an apparent gap in funding the real estate industry (Demirguc-Kunt and Klapper, 2014). UN-HABITAT (2014) reports that that unbanked population rely on their savings to finance their housing projects and when savings are nonexistent, they turn to informal sources.

The Kenyan population according to the 2009 census was 38.61 million but was estimated to be 46.7 million in 2016 (The World Factbook, CIA website). UNEP (2013) observes that the housing sector has been one of the fastest growing sectors attracting a lot of players into the industry. Kenya's annual housing deficit is above 200,000 and annual supply is 50,000 (UN-HABITAT, 2010; AfDB, 2013). The population of Nairobi in 2009 was about 3.138 million (2009 census), it was estimated to be 3.915 million in 2015 and the Kenyan rate of urbanization was $4.34 \%$ annual rate of change (2010 - 15 estimate) (The World Factbook, CIA website), the demand for housing is therefore high which means that a large proportion of development of housing units is in the city. Based on the population growth and the rate of urban migration the annual increase in demand is projected to grow to 156,000 , compounding the problem as there already 
exists a two million-unit backlog (AfDB, 2013).

Private commercial finance institutions, which provide credit at market rates, often avoid involvement in housing finance provision for low income groups due to the fact that they lack solid collateral, have low and (or) irregular incomes and thus possess high default risk, for these households often operate mostly in the informal economy and have therefore been excluded from accessing capital to build their houses (SINA Newsletter, 2007).

Technology is one the tools used to bring innovation in the financial sector, Saunders and Cornett, (2011) observed that it may impact a financial institution positively by enhancing product and service delivery, but some of the technologically based product innovations may turn out to be negative NPV projects. Technological advances do enable banks use better appraisal methods like discounted cash flow (DCF) methods (Myers, 2003).

Mobile banking can be used to bring about innovation in the provision of loans for housing especially to the low income sector of the economy. Economic Survey (2015); IMF (2015) report that use of mobile money transactions has been on the rise since its inception and Kenya boasts of having the world's leading mobile money system leading to increased financial inclusion.

Few studies look at the effect of economic factors on the supply-side of housing together with the effect of efforts taken by the financiers to boost uptake of credit by use of innovation and technology. Ndirangu and Nyamongo (2013), have looked at financial innovation in the banking sector; CAHF (2016); UN-HABITAT (2010, 2013, 2014), innovative housing finance; Wagura (2013), the supply side of housing but factors such as, price of houses, income per capita, inflation and interest rate (what this study would categorize as economic factors). Glossop (2008), the impact of housing on economic performance of cities in the UK, and Gibb, Maclennan and Stephens (2013), innovative financing of affordable housing in the UK and internationally.

\section{Literature Review}

\subsection{Theoretical Framework}

Underpinning this study are three main theories, the New Keynesian Theory, Schumpeter Innovation Theory, and the Stakeholders Theory. The first theory explains the economic situation that may impact funding, the second one explaining the impact innovation and technology may have on economic change, and the latter looking at the role and effect that stakeholders may have on the relationship between economic factors and funding for housing. The New Keynesian Theory explains the strong influence the monetary policy has on economic activity (Mankiw 2008). Prices of a good or service do not adjust quickly to changing economic conditions due to "stickiness" of prices, brought about by "menu costs" and aggregate-demand externalities, staggering price-setting and coordination failure. This friction gives rise to monetary non-neutrality and means that the competitive equilibrium outcome of the economy will, in general, be inefficient (Sims, 2012). This "stickiness" of prices then means that an increase in the money supply (decrease in the interest rate) does increase output and lower unemployment in the short run (Mankiw, 2008; Chugh, 2014; Benchimol and Fourçans, 2012; Benchimol, 2015), highlighting the government's role in improving macroeconomic conditions; such as countercyclical monetary or fiscal policy (Mankiw, 2008; Sims, 2012; Chugh, 2014). The Schumpeter Innovation Theory acts as the foundation for explaining how innovation and technology can bring about economic change. Schumpeter and other theorists have refined this theory over the years; where Schumpeter's (1934) original theory of innovative profits emphasized the role of entrepreneurship and the seeking out of opportunities for novel value-generating activities which would expand (and transform) the circular flow of income. He considered innovation as a major weapon in the competitive struggle whereby he conceptualized technological change and the institutionalization of research and development as integral drawing a clear distinction between the entrepreneurs whose innovations create the conditions for profitable new enterprises and the bankers who create credit to finance the construction of the new ventures (Schumpeter, 1939). Innovation in firms level can be achieved through the development of new products and services (technical innovation), or via new organizational and marketing methods (non-technological innovation) (Arundel, Kanerva, Van Cruysen, and Hollanders, 2007). The underlying philosophy of the Stakeholder theory emphasizes the "joint-ness" of the stakeholder interests and the need for all stakeholders to benefit over time through their cooperation (Freeman, 1984; Freeman, Harrison and Wicks, 2007).Value-creation both economic and non-economic should emanate from such a relationship (Argandona 2011; Bosse, Phillips and Harrison, 2009). This study concurs with these theories 1) by advocating the major role the government can play in boosting growth in housing, 2) recognition of the role innovation and technological advancement can bring to economic change in the banking sector, and 3) highlighting the importance of the major stakeholders in the construction industry.

\subsection{Review of Related Studies}

\subsubsection{Effect of Economic Factors on Funding of Housing}

This study confines itself to the supply-side of housing, but it has been demonstrated that the easy availability of credit for 
housing sector (non-food bank credit) at cheaper rates could increase the housing prices, Himmelberg, Christopher and Sinai (2005). Demand and supply of housing is of importance as stated by Piscetek, (2013) that price is a function of supply and demand therefore naturally, the price of housing is determined by housing supply and demand, and with an equilibrium price being realized when the demand for housing equals the supply of housing.

Supply of property is inelastic in the short-term because of time lags in construction and land release, changes in housing demand have a significant effect on housing costs as supply is not able to quickly respond to increases in demand (Gans and King, 2003). Saunders and Cornett (2011) observed that high interest rates indicate restrictive monetary policy action by the central bank and this makes financial institutions' lending decisions scarcer and more expensive, they concluded that high interest rates are correlated with higher credit risk. Rapid inflation does cause large increases in the cost of materials and land (Noppen 2012).

Ooi and Le (2012) used Vector Autoregressive (VAR) models to trace the price response of existing houses to the quantity of new units launched by homebuilders in Singapore between 1996 and 2009. They found that contrary to the "competition" hypothesis prediction of a negative reaction, they found that marginal supply Granger-cause existing house prices in a positive manner. The effect was robust to the inclusion of exogenous demand factors as well as price interaction in the primary (new houses) and secondary (existing houses) market segments.

The state of the macro economy affects growth in the housing sector through the wealth and collateral effects. The positive relationship between credit and house prices is in existence since a permanent increase in housing wealth leads to an increase in household spending and borrowing when homeowners try to smooth consumption over the life cycle, while the collateral effect of house prices emanates from the fact that houses are commonly used as collateral for loans because they are immobile and therefore easily accessible to a creditor. The higher house prices do induce homeowners to spend and borrow more, but also enhances their borrowing capacity (Goodhart and Hofmann, 2008).

Economic downturns characterized by high inflation, excessive interest rates, high taxes and volatile exchange rates lead to high costs and consequently reduced investment; and an effective strategic measure in development of affordable housing is lowering the cost of construction of affordable housing (Assaf, Bubshait and Al-Muwasheer 2010).

The study then sought to test the effect of Economic factors on Funding of housing. Thus the following hypothesis was specified.

\section{$H_{o}: \quad$ Economic factors do not influence the funding of housing}

$H_{1}$ : Economic factors do influence the funding of housing

\subsubsection{Effect of Innovative Financing and Technological Factors on Funding of Housing}

The link between finance and economic growth was first emphasized by Joseph Schumpeter in 1911, and in Schumpeter's theory, widely known as the theory of "creative destruction," innovation and entrepreneurship are the driving forces of economic growth. Sofat and Hiro (2007) in their comparative study on creativity and innovations in retail banking sector in India found that the existing challenge then for banks was to design and innovate financial products which were convenient to use and continuously meet financial goals of the customers.

Financial innovation as defined by Noyer (2007) is the emergence of new financial instruments and services, and of new forms of organization in more sophisticated and complete financial markets. Kola and Akinyele (2010); Potluri (2008) state that creating effective communication with customers is the most important aspect in services marketing.

The role of technology and innovation in the financial services industry is evolving rapidly (Donohue, Hooker, Lewis and Pryor, 2011) point out the great impact both have on the service providers and clients they serve and the benefits are numerous and include the promises of more informed, holistic decision-making, more powerful predictive capabilities and enhanced risk and compliance frameworks in which to operate.

Jha, Gupta, and Yadav (2008) while studying awareness, expectation and acceptance levels of the customers with respect to the use and effectiveness of the new technologies in banking sector in India found that the hectic lifestyle of the people where time is a scarce resource is the main factor that compels customers to use new techniques in banking. They noted a marked kind of popularity in new technology gadgets. CPSS (2012) noted that the trend towards speed is driven by both user demand and advances in technological capability.

To bridge the supply gap, business partnerships amongst various players; financial and non-financial, in the housing sector should be formed so as to provide a progressive housing process (UN-HABITAT, 2014), bringing together finance institutions, building materials retailers, manufacturers, banks, homebuilders, community organizations, service practitioners (architects, engineers, etc.), and governments. CPSS (2012) emphasized the importance of stakeholder's partnerships when it reported that the role of non-banks in retail payment innovations has increased significantly, owing in part to the growing use of innovative technology that allows non-banks to compete in areas such as mobile and internet payments which are not yet dominated by banks. Having building materials suppliers or service providers offer 
housing microfinance products such as savings, deposits and credit, then hiring finance institutions to facilitate the process would be an innovative way of financing (UN-HABITAT 2014).

Ndirangu and Nyamongo (2013) in their study of analyzing the effects of financial innovation in the banking sector on the conduct of monetary policy in Kenya during 1998-2012, using regression analysis and VAR framework, showed that the innovations have improved the monetary policy environment in Kenya as the proportion of the unbanked population has declined coupled with gradual reduction in currency outside banks and also that financial innovation has had positive outcomes and seems to improve the interest rate channel of monetary policy transmission.

Innovations in funding markets have had a significant impact on banks' ability and incentives to grant credit and, more specifically, on the effectiveness of the bank lending channel. Banks' greater reliance on market sources of funding has been a major innovation, be they traditional (the covered bond market) or the result of financial innovation (securitization activity), making the banks increasingly dependent on capital markets' perceptions (Gambacorta and Marques-Ibanez, 2011). Capital markets can also be roped in in the provision of funds for housing by use of REITs collective investment companies that own and typically operate income producing real estate or real estate related assets by providing a way for individual investors to earn a share of the income produced through commercial real estate ownership, without actually having to go out and buy commercial real estate (Afrane, Owusu-Manu, Donkor-Hyiaman and Bondinuba, 2014).

Adoption of tax credits in the housing sector can be an innovative way of offering incentives to developers like it is done in the US housing market. Gibb, Maclennan and Stephens (2013) highlight that the US's Low Income Housing Tax Credit (LIHTC) is a large-scale and significant programme, whose existence encourages other innovations in financing, design and project delivery.

The study then sought to establish the effect innovative financing and technological factors have on funding of housing in Kenya. The following hypothesis was then specified:

\section{$H_{o}$ : Innovative financing and technological factors do not influence the funding of housing}

$H_{1}$ : Innovative financing and technological factors do influence the funding of housing

2.2.3 Effect of Stakeholder Factors on Relationship between both Economic Factors and Innovative Financing and Technological Factors and Funding of Housing

Barney (2011) state that stakeholders are associated with an organization due to the utility they receive from such a relationship in various forms and this utility is based on perception. The main stakeholders in the construction industry are the developers, contractors, consultants, suppliers, financiers, the government, buyers and sellers in real estate and they do influence financing differently due to their unique interests. Moral issues concerning the stakeholders are of importance to the financiers.

Abdul-Rahman, Wang and Yap (2010) came to the conclusion that the issue of professional ethics play an important role in quality-related problems in a construction project in their questionnaire survey in the Malaysian construction industry. Chowdhury and Maung (2013) demonstrated empirically that increase in managerial efficiency increases firm's ability to acquire debt. Their argument was debt can also serve as a disciplining device and an increase in debt financing should also improve internal governance practices and indirectly compel the management to become more efficient.

Ameh and Odusami (2010) in their survey research assessed the perceptions of construction professionals regarding ethical issues in the Nigerian construction industry with a sample size of 108 construction organizations using descriptive statistics, posit that ethics affect corporate credibility and economic sustainability as well as personal security. Hassim et al. (2010) concur with this by pointing out that the construction industry plays a substantial role in a country's national economy, irrespective of the country's levels of economic development. Al-sweity (2013) found that the construction industry in the Gaza Strip suffer from ethical problems especially at the procurement stage, concluding that these unethical conducts have a negative impact in that it lowers profitability and quality of the projects

Mathenge (2012) in his investigation on the ethical issues facing the construction industry in Kenya, highlights that it is plagued by a lot malpractices due to unethical behavior of the stakeholders that have resulted in collapsing buildings that have been fatal.

The study then sought to examine the moderating effect of stakeholders on the relationship between Funding of housing and Economic factors. The following hypothesis was tested:

\section{$H_{o}$ : Stakeholders do not have a moderating influence on funding of housing \\ $H_{1}$ : Stakeholders have a moderating influence on funding of housing}

\section{Research Methodology}

A random sample of 212 financial institutions comprising commercial banks and micro finance institutions (MFIs) was drawn from a population of 451 branches in Nairobi got from 43 commercial banks, 9 deposit-taking MFIs and three other 
financiers (Shelter Afrique, East African Development Bank and International Finance Corporation) of housing in Kenya. The study tested for content validity based on expert opinion from in-depth interviews of experts in RE funding and academia. Construct validity was established by use of factor analysis. The data collection period was in the months of May and June 2015. Majority of the questions were Likert-type scales, with the other type of questions being single/multiple category scales i.e. dichotomous scales. Care was taken to ensure that the provided choices exhausted all possible responses to the question presented. The dependent variable funding was ordinal in that different categories of funding were provided ranging from less than KES 100 million to greater than KES 400 million with intervals of KES 100 million.

One hundred and fifty eight (158) questionnaires were collected, which translated to a response rate of 74.5 per cent. Factor analysis was used to see whether any data reduction was appropriate while descriptive analysis was used to draw out the different characteristics numerically; correlation analysis to establish if there existed any relationship between the independent variables (economic factors and innovative financing and technological factors) and the dependent variable (funding of housing). Several diagnostic tests were carried out to establish the suitability of the multiple regression analysis to be used, these are; multicollinearity to test the correlation of the independent variables, test of parallel lines to examine the equality of the different categories and whether the assumptions of the correlation between independent variables and dependent variable does not change for dependent variable's categories, also parameter estimations do not change for cut-off points held, lastly test of goodness of fit to test how well the model fits the data. The results of these diagnostic tests indicated that it was appropriate to use the ordinal logit regression analysis to test the relationship between the dependent and independent variables.

\section{Findings}

4.1 Descriptive Analysis - General Information

\subsubsection{Education of the Respondent}

The study found that $98.7 \%$ of the respondents had a first degree and higher therefore highly educated.

\subsubsection{Total Amount Lent out for Housing}

Credit for housing was categorized into different bands.

Table 1. Total Amount Lent out for Housing

\begin{tabular}{cccc}
\hline TOTAL AMT. LENT OUT (KES.) & Frequency & Valid Percent & Cumulative Percent \\
\hline$<100 \mathrm{~m}$ & 66 & 42.9 & 42.9 \\
$100-200 \mathrm{~m}$ & 33 & 21.4 & 64.3 \\
$201-300 \mathrm{~m}$ & 21 & 13.6 & 77.9 \\
$301-400 \mathrm{~m}$ & 6 & 3.9 & 81.8 \\
$>400$ & 28 & 18.2 & 100.0 \\
Total & 154 & 100.0 & \\
\hline
\end{tabular}

The study found that (Table 1) of the amount advanced for housing majority at $43 \%$ was worth less than KES. 100 million per branch, while $21 \%$ advance loans between KES. $100-200$ million and 14\% between KES. $201-300$ million. Only $22 \%$ advance loans for housing of more than KES. 300 million.

\subsubsection{Percentage of Total Loans Advanced, Average Default Rate and Average Lending Rate}

This helped bring out more of the characteristics on credit advanced for housing by a branch.

Table 2. Percentage Total Loans Advanced, Average Default Rate and Lending Rate

\begin{tabular}{cccc}
\hline & $\begin{array}{c}\text { Percentage of total loans advanced } \\
\text { from your branch for housing }\end{array}$ & $\begin{array}{c}\text { Average default rate observed in } \\
\text { housing in your branch }\end{array}$ & $\begin{array}{c}\text { Average Lending Rate } \\
\text { for Housing }\end{array}$ \\
\hline Mean & 32.9 & 6.3 & 16.33 \\
Median & 30.00 & 3.00 & 16.00 \\
Mode & 30.00 & 0.00 & 15.00 \\
Std.Deviation & 23.1 & 10.6 & \\
\hline
\end{tabular}

The study found that (Table 2) the average of the total loans advanced for housing by the Nairobi branches was $32.9 \%$ with a median and mode of $30 \%$. The average default rate on housing loans was $6.3 \%$ while the average lending rate $16.33 \%$. 


\subsubsection{Valuation Appraisal Method Commonly Used}

Adoption of technology in a financial institution enables it to use more sophisticated valuation methods in appraising projects.

Table 3. Valuation Appraisal Method Commonly Used

\begin{tabular}{l|l|c|c|c}
\hline \multicolumn{1}{l|}{ Appraisal Method } & Frequency & Valid (\%) & Cumulative (\%) \\
\hline Valid & Payback & 19 & 17.4 & 17.4 \\
\hline & Discounted Payback & 53 & 48.6 & 66.1 \\
\hline & NPV & 11 & 10.1 & 76.1 \\
\hline & IRR & 26 & 23.9 & 100.0 \\
\hline & Total & 109 & 100.0 & \\
\hline Missing & System & 49 & 31.0 & \\
\hline \multicolumn{2}{r}{ Total } & 158 & 100.0 & \\
\hline
\end{tabular}

When it comes to appraisal methods used for housing projects, the study found (Table 3) that only $17.4 \%$ of the financial institutions' Nairobi branches use the Payback method while majority at $48.6 \%$ used Discounted Payback method and the rest 34\% either used NPV or IRR methods.

\subsection{Factor Analysis}

The actual factor analysis used is the method of Principal Component Analysis and varimax rotation method. The two measures used in the study are (KMO) test and Bartlett's Test and they indicate the suitability of data for structure detection. Specifically, KMO measure of sampling adequacy is a statistic that indicates the proportion of variance in the variables that may be caused by underlying factors, while Bartlett's Test of sphericity tests the hypothesis that the correlation matrix is an identity matrix, which would suggest that the variables are unrelated and therefore unsuitable for structure detection.

\subsubsection{KMO and Bartlett's Test}

Table 4. KMO and Bartlett's Test for Economic Factor Construct

\begin{tabular}{lll}
\hline KMO- Measure of Sampling Adequacy. & & 0.462 \\
\hline Bartlett's Test of Sphericity & Approx. Chi-Square & 143.884 \\
\hline & df & 28.000 \\
\hline & Sig. & 0.000 \\
\hline
\end{tabular}

As shown in Table 4, KMO value is 0.462 and the chi square for Bartlett's Test is 143.884 with a p value of 0.000 . These two tests suggest that factor analysis is appropriate for economic factors.

Table 5. KMO and Bartlett's Test for Innovative financing and Technological factor Construct

\begin{tabular}{lll}
\hline \multicolumn{2}{l}{ KMO Measure of Sampling Adequacy. } & 0.801 \\
\hline Bartlett's Test of Sphericity & Approx. Chi-Square & 948.095 \\
\hline & df & 136 \\
\hline Sig. & 0.000 \\
\hline
\end{tabular}

As shown in Table 5, KMO value of 0.801 (greater than 0.5) and Bartlett's test had a value of 948.095 that was significant at 1 percent level indicating that innovation and technology construct can be factor analyzed.

Table 6. KMO and Bartlett's Test for Stakeholders Construct

\begin{tabular}{lll}
\hline \multicolumn{2}{l}{ KMO Measure of Sampling Adequacy } & 0.743 \\
\hline Bartlett's Test of Sphericity & Approx. Chi-Square & 242.532 \\
\hline & df & 6 \\
\hline Sig. & 0.000 \\
\hline
\end{tabular}

The value of KMO for stakeholders (Table 6) constructs was 0.743 (greater than 0.5) implying that stakeholders construct can be factor analyzed. The chi square for Bartlett's test was 242.532 with a p value of 0.000 that was significant at 1 percent level indicating that factor analysis is appropriate.

\subsubsection{Factor Analysis Results}

The main objective of factor analysis is (Blumberg, Cooper and Schindler, 2014) reducing many variables to a manageable number of variables that belong together and have overlapping measurement characteristics. 
Table 7. Rotated Component Matrix for Economic Factors

\begin{tabular}{|c|c|c|c|c|}
\hline Economic Factors & $\begin{array}{l}\overrightarrow{0} \\
\stackrel{8}{8} \\
\stackrel{8}{8}\end{array}$ & 丰 & 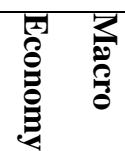 & 家 \\
\hline Prevailing Interest Rates & 0.094 & -0.096 & 0.133 & 0.870 \\
\hline Exchange Rates & -0.090 & -0.101 & 0.833 & 0.085 \\
\hline Inflation Rates & 0.069 & 0.220 & 0.768 & -0.052 \\
\hline Labor & 0.105 & 0.797 & 0.205 & 0.101 \\
\hline Raw Materials & -0.152 & 0.867 & -0.067 & 0.016 \\
\hline Competitors Lending Rates & -0.151 & 0.317 & -0.120 & 0.585 \\
\hline Demand of housing & 0.873 & 0.018 & 0.026 & -0.038 \\
\hline Supply of housing & 0.857 & -0.074 & -0.047 & 0.011 \\
\hline
\end{tabular}

The results in Table 7 presents factor analysis results for the economic factors construct. All the items had factor loadings greater than 0.5 indicating that all the items are strongly correlated with all the four components - Market forces, Cost of Inputs, Macro economy and Cost of Funding. Under Market Force, there was Demand of housing and Supply of housing which had factor loadings of 0.873 and 0.857 respectively. Labor costs and Raw Materials costs had factor loadings of 0.797 and 0.867 respectively, both under Cost of Inputs. Under Macro economy, there was Exchange rates and Inflation rates with factor loadings of 0.833 and 0.768 respectively. Prevailing interest rates and Competitors lending rates had factor loadings of 0.870 and 0.585 respectively both under Cost of funds. This indicated that economic factors can be measured using the four components.

Table 8. Rotated Component Matrix for Innovative Financing and Technological Factors

\begin{tabular}{|c|c|c|c|c|c|}
\hline Innovative Financing \& Technological Factors & 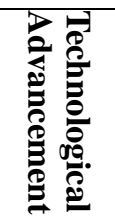 & 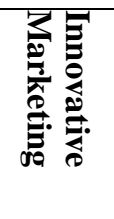 & 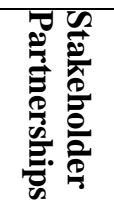 & 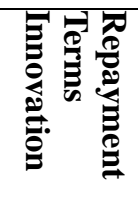 & 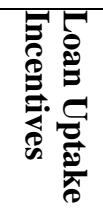 \\
\hline $105 \%$ Financing & -0.012 & 0.097 & 0.117 & 0.091 & 0.843 \\
\hline Moratorium on Repayments & -0.007 & 0.288 & 0.094 & 0.116 & 0.696 \\
\hline Create Awareness of Banks Products & 0.151 & 0.575 & 0.189 & 0.156 & 0.189 \\
\hline Provision of Long Tenors & 0.045 & 0.190 & 0.199 & 0.822 & 0.082 \\
\hline Flexible Loan Repayment & 0.005 & 0.240 & 0.023 & 0.836 & 0.120 \\
\hline Equity Release & 0.141 & 0.699 & 0.051 & 0.343 & 0.021 \\
\hline Interest Rate Rebates & 0.168 & 0.720 & 0.166 & 0.023 & 0.180 \\
\hline Partnerships with Mortgage Providers & 0.114 & 0.591 & 0.562 & 0.054 & 0.129 \\
\hline Partnerships with MFIs & 0.136 & 0.261 & 0.824 & 0.080 & -0.030 \\
\hline Partnerships with Consultants & 0.120 & 0.404 & 0.772 & 0.069 & 0.076 \\
\hline Partnership with Landlords & 0.169 & -0.088 & 0.636 & 0.202 & 0.233 \\
\hline Skilled Tech. Labor in Banking & 0.691 & 0.213 & 0.047 & 0.056 & -0.072 \\
\hline Better Appraisal Methods used & 0.784 & 0.278 & 0.122 & -0.026 & -0.068 \\
\hline Better Decision Making & 0.766 & 0.374 & 0.173 & 0.057 & 0.026 \\
\hline Boost because of Internet & 0.565 & -0.196 & 0.255 & 0.511 & 0.186 \\
\hline Mobile Banking Boost & 0.622 & -0.086 & -0.113 & 0.124 & 0.338 \\
\hline Satisfied Clients (Developers and Diaspora) & 0.653 & -0.001 & 0.319 & -0.047 & -0.077 \\
\hline
\end{tabular}

As shown in Table 8, all items under innovation and technology had factor loadings greater than 0.5 (rounded off to one decimal place) indicating that the items are strongly correlated with either component one, two, three, four, or five, which the researcher chose to represent dependent on the implied commonality of the items, Technological Advancement, Innovative Marketing Stakeholder Partnerships, Repayment Terms Innovation, and Loan Uptake Incentives. Under Technological Advancement had Skilled Tech. Labor in Banking, Better Appraisal Methods used, Better Decision Making, Boost because of Internet, Mobile Banking Boost and Satisfied Clients (Developers and Diaspora) with factor loadings of 0.691, 0.784, 0.766, 0.565, 0.622 and 0.653 respectively. Under component Innovative Marketing, were Create Awareness of Banks Products, Equity Release, Interest Rate Rebates, and Partnerships with Mortgage Providers, with loadings of $0.575,0.699,0.720$ and 0.591 respectively. Under component Stakeholder partnerships were Partnerships with Mortgage Providers, Partnerships with MFIs, Partnerships with Consultants, and Partnership with Landlords with factor loadings of $0.562,0.824,0.772$ and 0.636 , whereas those under component Repayment Terms Innovation were Provision of Long Tenors, Flexible Loan Repayment and Boost because of Internet with factor loadings of 0.822 , 0.836 and 0.511 . 105\% financing and Moratorium on Repayments had factor loadings of 0.843 and 0.696 respectively, and 
were correlated with component Loan Uptake Incentives. This finding indicated that innovation and technological factors can be measured using the five components.

Table 9. Component Matrix for Stakeholders Construct

\begin{tabular}{l|l}
\hline Stakeholder & Suitability in Their Field \\
\hline Contractors are Knowledgeable \& Competent & 0.790 \\
Consultants are Competent & 0.852 \\
Developers are Competent \& Trustworthy & 0.854 \\
Existence of Skilled Labor \& Good working conditions & 0.741 \\
\hline
\end{tabular}

As shown in Table 9, all items under stakeholder construct had factor loadings greater than 0.5 indicating that the items are strongly correlated with component Stakeholders' Suitability in their respective field of expertise. Factors; Contractors are Knowledgeable and Competent, Consultants are Competent, Developers are Competent \& Trustworthy and Existence of Skilled Labor \& Good working conditions had loadings of 0.790, 0.852, 0.854 and 0.741.

4.3 Descriptive Analysis

4.3.1 Respondents on Extent Effect of Economic Factors on Funding of Housing

Items listed below informed by literature review and the pilot study comprised what the study grouped under economic factors. Questions using the Likert scale sought to measure the degree of influence on funding of housing ranging from (i) Very Large Extent, (ii) Large Extent, (iii) None, (iv) Small Extent, (v) Very Small Extent.

Table 10. Extent Economic Factors Have on Funding of Housing

\begin{tabular}{l|c}
\hline & Very Large \& Large (\%) \\
\hline Market Forces & 87.3 \\
Demand of housing & 74.5 \\
Supply of housing & \\
Cost of Inputs & 47.7 \\
Labor & 70.3 \\
Raw Materials & \\
Macro economy & 74.4 \\
Exchange Rates & 41.7 \\
Inflation Rates & \\
Cost of Funds & 93.6 \\
Interest Rates & 67.7 \\
\hline
\end{tabular}

The responses in Table 10 were given as Very large and Large extent combined to give a percentage to measure effect of economic factors on funding of housing.

4.3.2 Respondents on Extent Effect of Innovative Financing and Technological Factors on Funding of Housing

Items listed below informed by literature review and the pilot study comprised what the study grouped under innovative factors. The respondents were asked to respond to each of the statements in terms of five degrees of agreement or disagreement on effect of the items on funding of housing. These ranged from (i) Strongly Agree, (ii) Agree, (iii) Neutral, (iv) Disagree, (v) Strongly Disagree. 
Table 11. Extent Innovative Financing and Technological Factors Have on Funding of Housing

\begin{tabular}{l|c}
\hline & $\begin{array}{c}\text { Strongly Agree \& Agree } \\
(\%)\end{array}$ \\
\hline Technological Advancement & 77 \\
\hline Skilled Technical Labor in Banking & 85 \\
\hline Better Appraisal Methods used & 81 \\
\hline Better Decision Making & 55 \\
\hline Boost because of Internet & 51 \\
\hline Mobile Banking Boost & 84 \\
\hline Satisfied Clients (Developers and Diaspora) & 84 \\
\hline Innovative Marketing & 89 \\
\hline Creation of Awareness of Banks Products & 70 \\
\hline Equity Release of Existing Property & \\
\hline Interest Rate Rebates & 90 \\
\hline Stakeholder Partnerships & 76 \\
\hline Partnerships with Mortgage Providers & 77 \\
\hline Partnerships with MFIs & 55 \\
\hline Partnerships with Building Consultants & \\
\hline Partnership with Landlords & 89 \\
\hline Repayment Term Innovation & 90 \\
\hline Provision of Long Tenors & \\
\hline Flexibility Loan Repayment Regimes & 73 \\
\hline Loan Uptake Incentives & 81 \\
\hline 105\% Financing & \\
\hline Moratorium on Repayments During Construction & \\
\hline
\end{tabular}

The responses in Table 11 above were given as Strongly agree and Agree combined to give a percentage to measure effect of innovative financing and technological factors on funding of housing.

\subsubsection{Respondents on Effect of Moderating Stakeholders Factors on Funding of Housing}

The effect of the suitability and competence of major stakeholders on funding of housing was sought.

Table 12. Extent Moderating Factors have on Funding of Housing

\begin{tabular}{l|c}
\hline & Strongly Agree \& Agree \\
\hline Suitability in their Fields & $\mathbf{( \% )}$ \\
\hline Contractors are Knowledgeable \& Competent & 83 \\
\hline Consultants are Competent & 83 \\
\hline Developers are Competent \& Trustworthy & 69 \\
\hline Existence of Skilled Labor \& Good working conditions & 67 \\
\hline
\end{tabular}

The responses in Table 12 above were given as Strongly agree and Agree combined to give a percentage to measure moderating factors effect.

\subsection{Correlation Analysis}

Correlation analysis is the statistical tool that can be used to describe the degree to which variables are linearly related to another.

\subsubsection{Correlation between Economic Factors and Funding of Housing}

Table 13. Correlation between Economic Factors and Funding of Housing

\begin{tabular}{|c|c|}
\hline & Economic Factors \\
\hline \multicolumn{2}{|c|}{ Funding for housing Pearson Correlation -0.022} \\
\hline Sig. (2-tailed) & 0.785 \\
\hline $\mathrm{N}$ & 154 \\
\hline
\end{tabular}


4.4.2 Correlation between Innovative Financing and Technological Factors and Funding of Housing

Table 14. Correlation between Innovative Financing and Technology factors and Funding of Housing

\begin{tabular}{cc}
\hline & Innovative Financing \& Technological Factors \\
\hline Funding of housing Pearson Correlation & -0.021 \\
Sig. (2-tailed) & 0.799 \\
$\mathrm{~N}$ & 153 \\
\hline
\end{tabular}

Table 14 shows the Pearson correlation coefficient between funding of housing and innovation and technological factors was -0.021 with a $\mathrm{p}$ value of 0.799 . This indicated a negative relationship between funding and innovative financing and technological factors, but it's not statistically significant

\subsubsection{Correlation between Funding of Housing and Stakeholders}

Table 15. Correlation between Funding of Housing and Stakeholders

\begin{tabular}{cc}
\hline & Stakeholders \\
\hline Funding of housing Pearson Correlation & -0.107 \\
Sig. (2-tailed) & 0.187 \\
$\mathrm{~N}$ & 154 \\
\hline
\end{tabular}

Table 15 presents the correlation results between stakeholders and funding of housing. Pearson correlation coefficient for the relationship between stakeholders and funding of housing was -0.107 with a $p$ value of 0.187 . This indicates that Funding for housing was negatively related with Stakeholders factors but the relationship was not statistically insignificant.

\subsection{Regression Analysis}

Multiple linear regression was used to establish the effect the independent variables (economic, and innovative financing and technological factors) have on the dependent variable (funding of housing) and also the effect of the moderating factors. Ordered logit regression was used since the dependent variable was a categorical variable that follows an increasing order.

\subsubsection{Regression Analysis - Economic Factors and Funding of Housing}

Table 16. Effect of Economic factors on Funding of Housing

\begin{tabular}{llll}
\hline Parameter & Estimate & Standard Error & Significance \\
\hline Economic Factor & -2.681 & 1.121 & 0.017 \\
\hline
\end{tabular}

The results for effect of economic factors on funding of housing show that the coefficient for economic factors was (Table 16) -2.681 with a $\mathrm{p}$ value of 0.017 . The significant $\mathrm{p}$ value implied that economic factors do significantly influence funding of housing; significant at $5 \%$. The negative sign of the coefficient indicated that the relationship between Economic factors and Funding of housing is negative.

According to the findings, the study rejected the null hypothesis that economic factors do not influence funding of housing.

4.5.2 Regression Analysis - Innovative Financing and Technological Factors and Funding of Housing

Table 17. Effect of Innovative financing and Technological Factors on Funding of Housing

\begin{tabular}{llll}
\hline Parameter & Estimate & Standard Error & Significance \\
\hline Innovative Financing and Tech. factors & -1.188 & 1.075 & 0.269 \\
\hline
\end{tabular}

The results shows that the coefficient for Innovative financing and Technological factors was -1.188 with a $\mathrm{p}$ value of 0.269 (Table 17). This $\mathrm{p}$ value is greater than 0.05 or 0.1 suggesting that the effect is insignificant.

The study failed to reject the null hypothesis and concluded that Innovative financing Technological factors do not significantly influence funding of housing.

4.5.3 Moderating Influence Stakeholders Have on Relationship between Funding of Housing and Economic Factors

Table 18. Moderating influence Stakeholders have on Funding of Housing and both Economic Factors and Innovative financing and Technological Factors

\begin{tabular}{llll}
\hline Parameter & Estimate & Standard Error & P value \\
\hline Stakeholders & 0.153 & 1.709 & 0.929 \\
Economic Factors and Stakeholders & 1.257 & 0.520 & 0.016 \\
Innovative financing and technological factors and Stakeholders & 0.682 & 0.411 & 0.097 \\
\hline
\end{tabular}


To test for the moderating effect the study used the regression method where the independent variables (Economic Factors, and Innovative financing and Technological Factors) were interacted with the moderator. The results (Table 18) showed that the coefficient between stakeholders construct and economic factors was 1.257 with a significant $p$ value of 0.016 ; thus, significant at $5 \%$. The moderating effect of stakeholders on innovative financing and technological factors was 0.682 and a $\mathrm{p}$ value of 0.097 , therefore significant at $10 \%$. The finding suggested that stakeholders moderate the relationships between both economic factors and innovative financing and technological factors and funding of housing.

\section{Discussion of Results}

The regression analysis results showed that there existed a negative relationship between economic factors and funding of housing and the coefficient was significant at 5 percent. This means that an upward shift in the items under economic factors will reduce the probability of an individual borrowing.

The results showed that demand for housing has a greater influence on funding of housing than supply. Market forces and government intervention (Warnock and Warnock, 2008) determine the specific size of each of the housing tenures. There are two major factors that influence the level of housing supply and the responsiveness of supply to changes in prices (Ball, Goody, Meen, and Nygaard, 2011), the first factor is the fixed supply of land and the requirement to allocate it among a number of economic and social uses i.e. the planning system and the rate at which land is released for development and the second factor is the long lead times in the construction of housing.

Cost of inputs, these being cost of labor and raw materials do not have a high effect on the availing credit for housing finance probably because these are not costs directly affecting the financial institutions. But it was found that cost of raw materials had a higher influence than cost of labor. This is in line with the cost structure of a single unit of housing (AfDB, 2013), $60 \%$ is the cost of construction that comprises $70 \%$ as the cost of materials with $30 \%$ of this being cost of labor. But this is in contrast with the findings of Wheaton and Simonton (2007) that there's no relationship found between construction costs and building activity.

Unstable macroeconomic factors negatively influence borrowing thus there would be a decline in borrowing for housing because of reduced disposable income. Exchange rates had a higher influence on funding of housing than inflation rates. Most of the materials used for finishes in housing are imported making the exchange rate significant. Kenya has adopted what is called inflation targeting (IMF, 2015) which has really worked very well in creating stability in the economy. Mallick, (2011) observes that the monetary policy can affect the construction sector especially the housing sector depending upon the credit allocation and interest rate policy in the economy. Prevailing interest rates were found to have a very big effect on funding of housing, together with competitors' lending rates. This was in contrast with the findings of Mbusi, Kenyatta and Kivaa (2013) that there is no significant relationship between changes in interest rates (they used CBK base lending rate as a representative) and the annual change in construction output, regardless of the number of years lagged

The study found that innovative financing and technological factors had no significant influence on funding of housing in Kenya. Some of the technological and innovative factors considered in the study were recent introductions; like provision of long tenors, flexibility of loan repayment regimes, equity release of existing property in housing, interest rates reduction on timely repayments, and modern technology like internet and mobile banking among others. The finding of an insignificant influence on funding of housing by innovations and technological advancements effected, could have been masked by macroeconomic factors. UN-HABITAT (2014) reports that the cost of land and building materials throughout Africa, is too high to make it profitable for developers and private construction companies, indicating it will take more than innovative financing and technological advancements to stimulate uptake loans for housing.

A positive moderating effect of the stakeholders on the relationship between economic factors and funding of housing was established by the study. UN-HABITAT, (2014) posit that Public-private partnerships have great potential for increasing accessibility of decent housing for the excluded people, where there's a high demand of housing in Kenya. The caliber of the different stakeholders in the construction industry does have a positive significant influence in the innovations and technological advancement in the funding of housing. The stakeholders' competence in their respective fields indicates a better understanding of the construction industry and does contribute in the introduction of innovative financing and technology.

\section{Conclusions}

The study has made significant contribution by first establishing a negative relationship between economic factors and housing, thus confirming what theory states, that intervention of the government through the central bank is necessary in the creation of an enabling environment for investment in housing. If the economic factors are unfavorable, the disposable income reduces and thus fewer funds are available to finance housing development. This is a clear demonstration of how vital a stable economy is to the funding of housing in Kenya for this creates confidence of potential housing lenders in the 
stability of the shilling and assurance that their investment in the sector will yield a good return. The study shows funding for housing is demand driven and that an unstable micro economic environment has a great effect on lending for housing. Interest rates were found to have the greatest effect on lending for housing, since it's the main determinant on how much funds will cost. The conclusion then being that the prevailing interest rates are prohibitive to allow uptake of housing loans at a level that will bridge the gap between demand and supply of housing.

The study also established that there's no significant relationship between innovative financing and technological factors and funding of housing in Kenya despite the aggressive efforts in the banking sector. Technological advancements and innovations in place do not seem to stimulate the uptake of loans for housing. The conclusion then is that technological advancement and innovation is a facilitator but not a motivator of funding.

Lastly, the study showed that major stakeholders in the construction industry namely; developers, contractors, consultants and labor force do play a significant role in upholding both the relationship between economic factors, and funding of housing and also the relationship between innovative financing and technological factors and funding of housing . Their suitability in their respective fields of expertise was important to those relationships.

\section{Recommendations}

Interest rates and exchange rates were found to have a big impact on credit provision in the housing sector, therefore to boost funding of housing in Kenya, the government and policy makers should ensure that interest rates are kept at a level that will encourage investments in housing. Volatility of the foreign exchange rate should be minimized to create stability since most building materials are imported.

The government could introduce more attractive tax incentives in the housing sector to spur growth as has been pointed out by UN-HABITAT (2013) that property tax incentives are intended to influence investment decisions and reward (or subsidize) certain economic activities, and this can encourage developers and the benefit would trickle down to potential home owners.

Innovative financing and technological factors were found to insignificantly influence funding of housing in Kenya. This means that as much as technology and innovation are important, it will have no major effect on the level of funding of housing in Kenya on its own. More needs to be incorporated to help boost funding in the housing sector with innovative financing in terms of new products and technology playing the role of a catalyst not a major factor.

\section{Limitations of the Study and Suggestions for Further Research}

A major limitation of this study was its confinement to only economic factors and innovative financing and technological factors influence on funding of housing in Kenya; other factors need to be incorporated. The effects of factors that do have an effect on funding in the housing sector needs to be studied over longer time periods thus need of use of longitudinal data.

In-depth research should be carried out on economic factors effect on funding of housing in Kenya looking at the demand side also. For innovative financing and technological factors more time needs to be given in order to assess their effect on funding of housing since most of the initiatives were recent therefore use of longitudinal data would also help.

\section{References}

Abdul, R. H., Wang, C., \& Yap, X. W. (2010). How professional ethics impact construction quality: Perception and evidence in a fast developing economy. Scientific Research and Essays, 5(23), 3742-3749.

AfDB. (2013). Africa Housing Dynamics: Lessons from the Kenyan Market, African Development Bank, Africa Economic Brief, 4(3).

Afrane, S. K., Owusu, M. D., Donkor, H. K. A., \& Bondinuba, F. K. (2014). Towards Innovative Housing Financing in Ghana: An Evidence Based from South Africa's Pension Housing Financing System. Public Policy and Administration Research. 4(4), 97-110.

Al Sweity, A. Y. (2013). Unethical Conduct among Professionals in Construction Industry. Working Paper. The Islamic University of Gaza.

Ameh, O., \& Odusami, K. (2010). Professionals Ambivalence toward Ethics in the Nigerian Construction Industry. Journal of Professional Issues in Engineering Education and Practice, 136(1), 9-16. https://doi.org/10.1061/(ASCE)1052-3928(2010)136:1(9)

Argandona, A. (2011). Stakeholder Theory and Value Creation. Working Paper, Interdisciplinary Conference on Stakeholders, Resources and Value Creation. https://doi.org/10.2139/ssrn.1947317

Arundel, A., Kanerva, M., Van Cruysen, A., \& Hollanders, H. (2007). Innovation Statistics for the European Service Sector, INNO Metrics Report. Brussels: European Commission, DG Enterprise and Industry. 
Assaf, S. A., Bubshait, A. A., \& Al-Muwasheer, F. (2010). Factors affecting affordable housing cost in Saudi Arabia. International Journal of Housing Markets and Analysis, 3(4), 290-307. https://doi.org/10.1108/17538271011080628

Ball, M., Goody, J., Meen, G., \& Nygaard, A. (2011). Housing Supply Revisited: Evidence from International, National, Regional, Local and Company Data. Department for Communities and Local Government, Eland House, Bressenden Place, London, 77.

Barney, J. B. (2011). Gaining and sustaining competitive advantage (4th Ed). Upper Saddle River, NJ: Pearson Education, Inc.

Benchimol, J. (2015). Money in the production function: a new Keynesian DSGE perspective. Southern Economic Journal, 82(1), 152-184.

Benchimol, J., \& Fourçans, A. (2012). Money and risk in a DSGE framework: A Bayesian application to the Eurozone, Journal of Macroeconomics, 34, 95-111. https://doi.org/10.1016/j.jmacro.2011.10.003

Bircan, C., \& Haas, R. (2015). The Limits of Lending: Banks and Technology Adoption across Russia. Working Paper Series. European Bank for Reconstruction and Development. No. 178. https://doi.org/10.2139/ssrn.2570842

Blumberg, B. F., Cooper, D. R., \& Schindler, P. S. (2014). Business Research Methods. McGraw-Hill Education.

Bosse, D. A., Phillips, R. A., \& Harrison, J. S. (2009). Stakeholders, Reciprocity and Firm Performance. Strategic Management Journal, 30(4), 447-456. https://doi.org/10.1002/smj.743

Brounen, D., De Jong, \& Koedijk, K. (2004). Corporate finance in Europe: Confronting Theory with Practice. Financial Management, 33(4), 71-101. https://doi.org/10.2139/ssrn.559415

Business Daily. (2015). M-Shwari lending more than triples to Sh. 24 bn. in one year. www.businessdailyafrica.com

CAHF. (2016). Centre for Affordable Housing Finance in Africa. Innovation in Housing Finance.

CBK. CBK website https://www.centralbank.go.ke/.../credit-reference-bureaus

Chowdhury, R. H., \& Maung, M. (2013). Corporate entrepreneurship and debt financing: evidence from the GCC countries. International Journal of Managerial Finance, 9(4), 294-313. https://doi.org/10.1108/IJMF-11-2012-0124

Chugh, S. K. (2014). Chapter 12, New Keynesian Economics, pp. 163-186; in Modern Macroeconomics, MIT Press.

CPSS. (2012). Committee on Payment and Settlement Systems. Innovations in Retail Payments. Working Group on Innovations in Retail Payments. Bank for International Settlements, ISBN 92-9131-127-8.

Demirguc, K. A., \& Klapper, L. (2014). The Global Findex Database 2014: measuring financial inclusion around the world. The Global Financial Inclusion (Global Findex) database, World Bank.

Doling, J., Vandenberg, P., \& Tolentino, J. (2013). Housing and Housing Finance-A Review of the Links to Economic Development and Poverty. ADB (Asian Development Bank) Economics Working Paper Series. No. 362. https://doi.org/10.2139/ssrn.2309099

Donohue, J., Hooker, M., Lewis, C., \& Pryor, W. (2011). The Evolving Role of Technology in Financial Services. State Street Financial Center.

Economic Survey. (2015). Kenya National Bureau of Statistics.

Freeman, R. E. (1984). Strategic management: A stakeholder approach. Cambridge, Mass: Ballinger.

Freeman, R. E., Harrison, J. S., \& Wicks, A. C. (2007). Managing for stakeholders: survival, reputation, and success. New Haven, CT: Yale University Press.

Gambacorta, L., \& Marques, I. D. (2011). The bank lending channel: Lessons from the crisis. BIS Working Papers: 345. Monetary and Economic Department.

Gans, J., \& King, S. (2003). Policy Options for Low Income Households. Melbourne: University of Melbourne.

Gibb, M., Maclennan, D., \& Stephens, M. (2013). Innovative financing of affordable housing: International and UK Persepective. Joseph Rowntree Foundation

Glossop, C. (2008). Housing and economic development: Moving forward together, Housing Corporation, Centre for Research and Marketing Intelligence. Centre for Cities.

Goodhart, C., \& Hofmann, B. (2008). House Prices, Money, Credit and the Macroeconomy. European Central Bank Working Papers Series: The Social Science Research Network, No. 888.

Hassim, A., Kajewski, S., \& Trigunarsyah, B. (2010). Factors Contributing To Ethical Issues in Project Procurement Planning: A Case Study in Malaysia. Proceedings of the 8th International Conference on Construction and Real 
Estate Management. Royal on the Park Hotel, Brisbane, Queensland.

Himmelberg, C., Christopher, M., \& Sinai, T. (2005). Assessing High House Prices: Bubbles, Fundamentals, and Misperceptions, Journal of Economic Perspectives, 19(4), 67-92. https://doi.org/10.1257/089533005775196769

International Monetary Fund (IMF). (2015). Evolving Monetary Policy Frameworks in Low-Income and Other Developing Countries. Electronic copies of IMF Policy Papers. http://www.imf.org/external/pp/ppindex.aspx.

Jha, B. K., Gupta, S. L., \& Yadav, P. (2008). Use and Effectiveness of New Technologies in Indian Banking: A Study. ICFAI Journal of Services Marketing. 6(1), 6-22.

Kola, O., \& Akinyele, S. T. (2010). Evaluation of Effectiveness of Marketing Communication mix element in Nigerian Service Sector. Pakistan Journal of Social Sciences, 7(2), 76-80. https://doi.org/10.3923/pjssci.2010.76.80

Mallick, H. (2011). Monetary policy, construction sector output and housing prices in India: an emerging economy perspective. Euro-American Association of Economic Development Studies.

Mankiw, N. G. (2008). New Keynesian Economics. Library of Economics and Liberty, Liberty Find Inc.

Mathenge, G. D. (2012). Ethical Issues in the Construction Industry in Kenya: A Critical Analysis of the Professional Conduct in Engineering Technology Management. Industrial Engineering Letters, 2(7). www.iiste.org.

Mbusi, E. T., Kenyatta, M. O., \& Kivaa, T. (2013). Influence of interest rates on construction industry output in Kenya. Department of Construction Management, Jomo Kenyatta University of Agriculture and Technology, Nairobi

Mondejar, R., Cheung, S., \& Suen, H. (2007). Teaching and Learning Ethics: The Construction Manager's Perspective. CIB World Building Congress, Cape Town, South Africa, 2220-2233.

Myers, D. G. (2003). Foreword. In W. Damon, Noble purpose. Philadelphia: Templeton Foundation Press

Ndirangu, L., \& Nyamongo, E. (2013). Financial Innovations and Monetary Policy in Kenya. Journal of African Economies, 24(1), i46-i71.

Noppen, A. (2012). The ABC's of Affordable Housing in Kenya. Acumen Fund.

Noyer, C. (2007). Financial innovation, monetary policy and financial stability. Speech by Governor of the Bank of France, at the Spring Conference of the Bank of France/Deutsche Bundesbank, Eltville, Germany.

Ooi, J. T., \& Le, T. T. (2012). New Supply and Price Dynamics in the Singapore Housing Market. An International Journal of Research in Urban Studies, 49(7), 1435-1451. https://doi.org/10.1177/0042098011415718

Piscetek, M. (2013). The Economics of Affordable Housing: An investigation into the Western Australian residential property market. Working Paper: School of Economics and Finance, Curtin University.

Potluri, R. M. (2008). Assessment of Effectiveness of Marketing Communications Mix Elements in Ethiopian Service Sector. African Journal of Business Management, 2(3), 059-064.

Sa, F., Towbin, P., \& Wieladek, T. (2011). Low interest rates and housing booms: The Role of capital inflows, monetary policy and financial innovation Bank of England. Working Paper No. 411. https://doi.org/10.2139/ssrn.1765853

Saunders, A., \& Cornett, M. M. (2011). Financial Institutions Management: A Risk Management Approach, McGraw-Hill/Irwin; 7th Edition.

Schumpeter, J. A. (1934). The Theory of Economic Development, Cambridge, Mass.: Harvard University Press (originally published in German in 1911; reprinted by Transaction Publishers, New Brunswick, New Jersey in 1997).

Schumpeter, J. A. (1939). Business Cycles: A Theoretical, Historical, and Statistical Analysis of the Capitalist Process. New York: McGraw-Hill.

Sims, E. (2012). Intermediate Macroeconomics: New Keynesian Model. Working Paper, University of Notre Dame.

SINA Newsletter. (2007). Strategies for affordable housing finance in Sub-Saharan Africa. Settlement Information Network Africa.

Sofat, R., \& Hiro, P. (2007). Creativity and Innovations in Retail Banking: A Comparative Analysis of Financial Product Offered by ICICI \& HDFC Banks. Indian Journal of Marketing, 9, 24.

The World Factbook, Central Intelligence Agency (US) website. https://www.cia.gov/library/publications/the-world-factbook/geos/ke.html.

UNEP. (2013). Sustainable Building Policies in Developing Countries (SPoD): Local Situation Review - Kenya. United Nations Environment Programme.

UN-HABITAT. (2010). The Organization, Management and Finance of Housing Cooperatives in Kenya. The Global 
Urban Economic Dialogue Series.

UN-HABITAT. (2013). Property Tax Regimes in East Africa. The Global Urban Economic Dialogue Series

UN-HABITAT. (2014). Shelter Report Step by Step: Supporting Incremental Building through Housing Microfinance, Habitat for Humanity International

Wagura, J. T. (2013). Determinants of Housing Supply in Kenya. Working Paper, School of Built Environment. University of Nairobi.

Warnock, V., \& Warnock, F. (2008). Markets and Housing Finance. Journal of Housing Economics, 17. https://doi.org/10.1016/j.jhe.2008.03.001

Wheaton, W. C., \& Simonton, W. E. (2007). The Secular and Cyclic Behavior of 'True' Construction Costs, The Journal of Real Estate Research, 29(1), 1-26.

\section{Copyrights}

Copyright for this article is retained by the author(s), with first publication rights granted to the journal.

This is an open-access article distributed under the terms and conditions of the Creative Commons Attribution license which permits unrestricted use, distribution, and reproduction in any medium, provided the original work is properly cited. 